the

italianist

thirty-seven

$2017 \cdot 3$

\section{The Italianist}

ISSN: 0261-4340 (Print) 1748-619X (Online) Journal homepage: http://www.tandfonline.com/loi/yita20

\title{
Characterization and eschatological realism from Dante to Petrarch
}

\section{Laurence Hooper}

To cite this article: Laurence Hooper (2017) Characterization and eschatological realism from Dante to Petrarch, The Italianist, 37:3, 289-307, DOI: 10.1080/02614340.2017.1407987

To link to this article: https://doi.org/10.1080/02614340.2017.1407987

册 Published online: 16 Mar 2017.

Submit your article to this journal ¿

Q View related articles $₫$

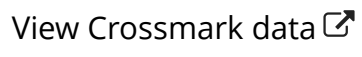




\title{
Characterization and eschatological realism from Dante to Petrarch
}

\author{
Laurence Hooper \\ Dartmouth College, USA
}

\begin{abstract}
This article considers the characterization of blessed souls in Dante's Commedia (1307-21) and Petrarch's Canzoniere (c. 1356-74) and Triumphi (c. 1352-74). It argues that eschatological realism - the detailed representation of souls in the afterlife - lies at the heart of these three works, each of which depicts a deceased beloved who now resides in Paradise. Dante's Paradiso navigates a range of doctrinal and literary challenges to incorporate its blessed characters into the poem's continuum of interlocutors. Although the Commedia culminates with a first-person, mystical experience, the structural importance of third-person voices to the canticle demonstrates the centrality of realist characterization to the overall project. Petrarch's works, meanwhile, reject Dante's broad and varied descriptions of beatitude but nonetheless assert a more restricted eschatological realism channelled through the interpersonal connection with Laura. The beloved's combination of exemplarity and historicity sets up the paradigm that defines the other characters in Petrarch's narrative, including the poetic ' $I$ '.
\end{abstract}

\section{SOMMARIO}

L'articolo si concentra sul caratterizzare delle anime beate nella Commedia di Dante, nonché nel Canzoniere e nei Triumphi di Petrarca. Si propone che il realismo escatologico, cioè la raffigurazione dettagliata delle anime nell'aldilà, stia a cuore di tutte e tre opere, ognuna delle quali narra di un'amata defunta ora residente in Paradiso. Nel suo Paradiso, Dante travalica vari ingombri di natura sia dottrinale, sia letteraria per arrivare a includere i personaggi beati nella sequenza di interlocutori del poema. Benché la Commedia culmini in un'esperienza mistica in prima persona, l'importanza strutturale delle voci di terza persona dimostra la centralità della caratterizzazione realista al progetto complessivo. Le opere petrarchesche, invece, pur respingendo le descrizioni dantesche della beatitudine, piuttosto ampie e variegate, tuttavia esibiscono un realismo escatologico più stretto perché incanalato nella connessione interpersonale con Laura. La combinazione di esemplarità e storicità caratteristica dell'amata donna stabilisce un paradigma determinante per tutti gli altri personaggi della narrativa petrarchesca, l'io narrante compreso.

\section{KEYWORDS}

Characterization; beatific vision; verisimilitude; legal fiction; Dante; Petrarch

\section{PAROLE CHIAVE}

Caratterizzazione; visione beatifica; verosimiglianza; fictio iuris; Dante; Petrarca 
Se fu beato chi la vide in terra,

or che fia dunque a rivederla in cielo?

(Petrarch, Triumphus Eterntitatis, 144-45).

\section{Introduction}

This essay will concentrate on the characterization of departed souls in Dante's Commedia and Petrarch's Canzoniere and Triumphi. At the centre of this trio of vernacular narrative works stands the figure of the beloved lady who has passed on to Heaven. The literary process of characterization therefore entwines with the theological question of how far, if at all, one may represent the ultimate truth of salvation. Although there are important differences between the two poets' approaches, both adopt a moderate eschatological realism in characterizing saved souls. By this, I mean that they consider detailed depictions of the blessed as permissible and indeed desirable under certain conditions.

The notion that the Commedia's diverse cast of souls, angels and devils offer a true representation, not only of matters affecting this world but also of salvation and damnation, is fundamental to the modern tradition of Anglo-American Dante criticism. ${ }^{1}$ Petrarch, meanwhile, overtly rejects the charge that his Laura 'was completely invented, my poems fictitious and my sighs feigned'. ${ }^{2}$ But eschatological realism was profoundly controversial for fourteenth-century readers because it implied the poet's personal knowledge of eternal, mystical truths. All of Dante's early commentators, for example, stress the fictionality of his poem's plot. ${ }^{3}$ What follows will adduce contextual material from contemporary legal sources and theological debates that sheds light on this unwillingness to accept Dante's descriptions of the afterlife as verisimilar.

Of course, Petrarch shared the intellectual and cultural milieu of the Trecento commentators so these considerations will likewise illuminate his poetic response to Dante's work. As Dante's traditional antithesis in the critical literature, influential analyses tend to depict an antirealist 'Petrarca senza storia'. ${ }^{4}$ Gianfranco Contini's division of Italian literature into a Dantean strand - plurilingual, expressionist, historicizing - and a Petrarchan one - monolingual, clasissizing, ahistorical - continues to foster this perceived opposition. ${ }^{5}$ In fact, we shall see that Petrarch is open to an eschatologically realist approach in his own poetry, within new limits that changing theological orthodoxy had placed on such expression. Over and above the essential salvific figure of Laura, Petrarch's vernacular poetry also considers the salvation of numerous other friends and acquaintances. And so, on the specific question of representing departed souls in bliss, the Paradiso represented a unique and unavoidable interlocutor.

\section{The place of realism in medieval theories of characterization}

As is typical in realist texts, the characters in Dante and Petrarch's narrative works function as ethical models and as mediators to the narrative situation they inhabit, including the afterlife as appropriate. ${ }^{6}$ This implies an underlying theoretical structure that is undeniably realist: the value of these works rests on their capacity to encompass external truth within a narrative centred on concrete and recognizable contemporary figures. ${ }^{7}$ From Roland Barthes's 'reality effect' of Flaubert describing a piano, to Jacques Le Goff on the 'realist evocations of customs and behaviours' in collections of 
exemplary narratives for medieval preachers, ${ }^{8}$ narratives from all time periods are commonly termed realist where they combine 'internal logico-semantic cohesion' with a plot and characters that fit into 'the general course of contemporary History'. ${ }^{9}$

Although realism was not a recognized literary term in the Middle Ages, its essential techniques, including verisimilitude, detailed exposition and a concentration on everyday life were recognized in classical rhetoric. ${ }^{10}$ The secular rhetoric of late medieval Italy, both in Latin and the vernacular, follows a Ciceronian model focused on successful and appropriate communication. ${ }^{11}$ Ciceronian figures related to characterization include: effictio (Italian mostramento), a brief sketch highlighting essential traits; ${ }^{12}$ notatio (Italian disegnare), a more extended description of 'li reggimenti della natura d'alcuna persona, [...] i quali [...] sì come certi segni sono dati a I'uomo' ${ }^{13}$ and sermocinatio (Italian sermonare), 'quando il dicitor favella in luogo d'un'altra persona'. ${ }^{14}$

It may surprise us that rhetoricians deemed effictio more definitive than its longer counterpart: a brief description was reserved for a person whose relevance to the overall discourse was unquestioned, while a fuller explanation implied a digression to exemplify a relevant quality, which thus took precedence over the character's identity. ${ }^{15}$ This rejection of superfluity in description, what Barthes calls 'narrative luxury', discourages the use of 'reality effects' to contextualize the narrative in history; ${ }^{16}$ as we shall see, it is a precept both Dante and Petrarch breach in significant ways.

Another key feature of the characters in these works is that they always already exist in another book: the Bible, a classical or medieval source, the historical record, the 'book of Creation'. The narratological term for the introduction into a work of characters who exist outside of it is versioning. ${ }^{17}$ The technique naturally emphasizes a work's literary qualities by suggesting that its characters are not inventions ex nihilo but rather commentaries on and reworkings of prior texts.

The medieval rhetorical figure that relates most closely to versioning was the exemplum, which, by the late thirteenth century, had become a central feature of medieval preaching. ${ }^{18}$ In the process, the exemplum had expanded greatly from its classical definition - 'what happens when we describe with our words some fair saying or deed of a wise and celebrated person'19 - to 'a brief narrative presented as truthful (that is, historical) and used in discourse (usually a sermon) to convince listeners by offering them a salutary lesson'. ${ }^{20}$ Where civic rhetoricians usually peopled their treatises with ancient pagan figures, ${ }^{21}$ preachers preferred well-known modern personages to help the listener to grasp the continuing relevance of biblical precepts. ${ }^{22}$ In sum, the medieval religious exemplum privileges a historicity of recency in its characters, as would realist narrative centuries later.

For Dante, the exemplum, with its familiar stories and humble diction, is an important means of introducing theological material into his work in a realist manner - i.e. through recognizable characters from recent history. ${ }^{23}$ The Commedia marks a watershed in Italian literary history: with Dante's poem, and with the parallel emergence of the novella tradition, secular narrative begins to record large numbers of contemporary lives. ${ }^{24}$ Thereafter, it will seem unremarkable for historical voices from the recent past to play an essential mediating role between the poetic self and external truth. ${ }^{25}$ The social range of characters in Petrarch's works is more restricted than Dante's. Nonetheless, without Dante's validation of the recent past, it remains impossible to imagine 
the centrality of Laura to Petrarch's poetic identity, or even the promise made by the mysterious guide figure of the Triumphi: 'vero amico / ti son, e teco nacqui in terra tosca'. 26

\section{The triumph of realism in paradiso}

Authors of preaching manuals esteemed exempla because they made mystical truths more palpable and thus more comprehensible for the listener. ${ }^{27}$ Similarly, the realism of the Commedia is founded in its characters: eternal immaterial souls made recognizable to its human readers thanks to their earthly deeds and attributes. ${ }^{28}$ In Paradiso XXXIII, Bernard of Clairvaux stresses the essential continuity of the Pilgrim's journey, and especially of the departed souls whom he has met across Hell, Purgatory and Heaven. ${ }^{29}$

Or questi [Dante], che da l'infima lacuna

de l'universo, infin qui ha vedute

le vite spiritali ad una ad una.

(Par. XXXIII. 22-24)

In a study of characterization in the Commedia, I have drawn a distinction between the work's static and dynamic characters based on the notion that 'every [third-person] character either joins with the protagonist's journey for a time or delays it while the two parties interact'. ${ }^{30}$ Static characters, like Francesca da Rimini (Inf. V) represent the classic case of 'an encounter between the protagonist and a character located in a given zone of the afterlife who represents or exemplifies that place's moral virtue or vice'. ${ }^{31}$ In rhetorical terms, they may be described with effictio (e.g. Gianni Schicchi, Inf. XXX) or notatio (e.g. Pier delle Vigne, Inf. XIII). Dynamic characters, like Virgil or Beatrice, 'move through the different zones both of the poem and of the afterlife' and have 'structurally significant roles in the poem, surpassed only by the narrator himself'. ${ }^{32}$ They are almost always described using notatio at some point, although effictio may occur in the case of repeated interventions, as with Matelda's 'ladylike' reminder of Statius's continued presence at the end of the Earthly Paradise cantos (Purg. XXXIII. 133-35).

However, the blessed souls of Heaven are different from other departed persons in that they enjoy the beatific vision of God, which ought to remove them from the bodily methods of positioning, distinguishing and ranking that are essential both to static and dynamic types of characterization. In essence, Paradiso demands a novel form of realism in order that the blessed souls can form the continuum with the damned and the penitent to which Bernard refers.

Dante supplies a doctrinal explanation for the corporeal realism of his characterization in Inferno and Purgatorio via the concept of the shade (ombra). ${ }^{33}$ Statius explains that departed souls who remain on Earth, whether permanently in Hell or temporarily on Mount Purgatory, form the surrounding air into a pseudo-body, capable of undergoing any experience conforming to Divine Justice (Purg. XXV. 88-107). In the following canto, the lustful souls provide further context by dubbing their virtual physicality a 'corpo fittizio' (Purg. XXVI. 12).

The term the souls use reflects a concept from medieval law, corpus fictivum, which indicates the imagined presence of an absent or deceased person like the testator in a will. ${ }^{34}$ Just as the pseudo-bodies of the souls in Hell and Purgatory have only those functions deemed necessary by Divine Justice, jurists delimited the situations in which 
one could conjure up a fictitious body according to the laws of nature - understood as the terrestrial expression of God's ordained power (potestas ordinata). ${ }^{35}$ Like the fictional characters of the realist novel, the corpus fictivum of the damned and penitent is a supplement to reality that nonetheless follows its essential rules. ${ }^{36}$ In the Middle Ages, these rules are synonymous with natural law, meaning that, despite their unconventional 'narrative luxury', Dante's fictitious bodies are at once realist and ethically motivated, as medieval literary theory requires. ${ }^{37}$

Statius does not mention the blessed; moreover, the characters of Paradiso ordinarily inhabit the Empyrean, a place beyond the finite universe and its natural law: 'dove Dio sanza mezzo governa / la legge natural nulla rivela' (Par. XXX. 122-23). ${ }^{38}$ Most of the canticle adopts a temporary solution: the Pilgrim encounters the blessed outside the Empyrean in the finite celestial spheres. Here natural philosophy can apply, although Dante does not make clear exactly how far in the case of blessed souls. Instead, the location in space and time of Paradiso's static characters is implied by the continuation of the Commedia's realist characterization processes: encounters with exemplary figures rooted both in the contemporary world and in the afterlife via the 'reality effects' of description and dialogue. ${ }^{39}$

The first three heavens that the Earth's shadow touches are especially important to establishing the possibility of realist characterization in Paradiso, as we shall see below via a close examination of the figure of Justinian. Souls like Piccarda Donati share completely in the beatific vision yet continue to be 'ombre' because of the shadow of sin that they bear (Par. III. 34-36). ${ }^{40}$ The continued use of the term ombra implies a resemblance between the way in which the characters of the Paradiso manifest and the aerial bodies of non-saved souls. ${ }^{41}$ Moreover, it confirms that the third canticle will maintain the poem's realist narrative structure of dialogue between the protagonist and pseudo-corporeal characters whose location and movements in time and space have an exemplary value.

It seems implicit that the physics of the heavenly spheres, where the celestial element aether ('etera') replaces the four earthly elements, allows the blessed souls to take on a form localized in space: ${ }^{42}$ an aethereal body, analogous to the aerial bodies of the damned and penitent. Both times Dante mentions aether, he makes clear that the triumphant souls of Heaven affect it via proximity, just as the souls still on Earth affected the surrounding air. ${ }^{43}$ However, the second, more explicit, mention of this process (Par. XXVI. 69-70) comes at the point where the blessed are returning from the spheres to the Empyrean and the artificiality of the notion of a static character in Paradise is at its clearest.

Even assuming that an aethereal body explains the souls' appearances in the spheres, some other mechanism must underpin the continuation of realist characterization into the Empyrean: the humanizing descriptions of Bernard of Clairvaux and Beatrice, or a detail like the different hair colours that still distinguish Jacob and Esau. ${ }^{44}$ Bernard's invitation to Dante, 'riguarda omai ne la faccia che a Cristo / più si somiglia' (Par. XXXII. 85-86), highlights the unique presence of Mary's resurrected body among the blessed and the provisional nature of any representation of the other souls. In the absence of aether and natural law, medieval canon law and theology offer another kind of fictitious body in which the blessed of the Empyrean can participate: the indivisible corpus mysticum of the Universal Church. ${ }^{45}$ While they await the resurrection of their bodies, the saved souls are nevertheless members of this corporate body: 'a mystical entity really existing outside the world of particulars, [...] on a level with the species and genera which alone have true reality'. ${ }^{46}$ Aside from 
Mary, the human forms that Dante glimpses in the Empyrean cantos are of a piece with the mystical imagery of sparks, water, flowers, etc. he also evokes: they are real in a way that only transcendence allows.

The concept of the corpus Ecclesiae mysticum is at its most apparent in the many corporate terms applied to the blessed in the Empyrean, 'cort[e]', 'regno', 'convento', or 'città' (Par. XXX. $96,98,129,130$; cf. 'la corte del cielo', Inf. II. 125), and especially in its similarity to Rome. ${ }^{47}$ But it is operative throughout the Paradiso, especially where Dante speaks of the blessed as full human persons who enjoy beatitude through the combination of soul and corporate body. Hence the many collective, symbolic expressions of heavenly bliss that dot the cantos of the finite spheres: the circular dance of the Heaven of the Sun; the souls in Mars arranging themselves into a crucifix; the just in Jupiter spelling out a biblical verse, the final ' $\mathrm{m}$ ' of which then becomes a talking eagle; the replica of Jacob's Ladder in Saturn; and the Triumphs of Christ and Mary in the Sphere of Fixed Stars.

These corporate figurations of beatitude model for the pilgrim and the reader the possibility of membership in a polity of the saved - provisionally on Earth and eternally in Heaven. Beatrice sums this up with her promise to the pilgrim in Eden: 'Qui sarai tu poco tempo silvano; / e sarai meco sanza fine cive / di quella Roma onde Cristo è romano' (Purg. XXXII. 100-02). Her description of the Empyrean as an analogue of the Eternal City presages the descriptions of it in Paradiso XXX-XXXII, connecting even this transcendent locale to a geographically and historically located site. ${ }^{48}$ Meanwhile, the first half of the promise - 'Qui sarai tu poco tempo silvano' - attributes to Dante the legal status of 'sylvan citizen' vis-à-vis Heaven: ${ }^{49}$ he is a lawful newcomer from outside the city walls who must meet certain obligations to consummate his naturalization. ${ }^{50}$

Beatrice's connection of Heaven and Rome is part of a sustained and technical figuration, known in medieval Latin as transumptio, ${ }^{51}$ which connects the earthly city to the civitas Dei. One significant aspect of Roman culture Dante consistently highlights is the triumph: ${ }^{52}$ an event designed to imbue historical reality with sacred meaning. ${ }^{53}$ The application of triumphal imagery to Christian beatitude was already common before Dante. $^{54}$ Drawing on this pre-existing syncretism, the Paradiso's triumphal imagery suggests a continuity between the imperial might of Pagan Rome and the eschatological victory wrought by Christ's resurrection.

The transumptio of the triumph begins in the Earthly Paradise (Purg. XXVIII-XXXIII) and recurs consistently thereafter until the pilgrim reaches the new Rome of the Empyrean. In Eden, Dante sees a Christianized version of a pagan triumph: a great procession of symbolic figures who parade before a chariot bearing a Christlike Beatrice. ${ }^{55}$ In the Heaven of Fixed Stars, meanwhile, he witnesses a triumph more in line with the iconography of the Ascension and Transfiguration. ${ }^{56}$ 'Le schiere / del trïunfo del Cristo' (Par. XXIII. 19-20) gather as Christ and Mary appear in their resurrected bodies before ascending to the Empyrean.

The Emperor Justinian (Cantos V-VII) is both an important participant in the metaphorical filigree of the triumph, ${ }^{57}$ and a key figure for understanding the Paradiso's eschatological realism. Justinian famously has the distinction of being the only character in the poem to speak for an entire canto uninterrupted. This singular instance of sermocinatio appears fitting given Justinian's rationalization of Roman law into 'a single codex which brought together the scattered writings of so many authors'. ${ }^{58}$ And yet the Earth's shadow that touches Justinian is a reminder of how worldly ambition, 
even when aimed at justice, tends to toward the sin of pride. On Earth he was Inclutus Victor ac Triumfator; in Heaven, however, the earthly shadow that shrouds Justininan rounds out his characterization with human error and ambiguity. One could read his total occupation of Paradiso VI as the grandiose solitude of the sovereign who demands 'no jurist shall hereafter dare to attach commentaries to [the Digest]' ${ }^{59}$

Justinian's narrative prominence stands in instructive contrast to the other Roman emperor who appears as a character in Paradiso: Trajan. Although he is located far above Justinian in the Heaven of Jupiter, Trajan's characterization is much less rich and we receive little insight into his personality. ${ }^{60}$ In Paradiso $\mathrm{XX}$, a terse effictio recalls his charitable response to a poor widow's petition for justice (43-48). This turn refers back to the fuller account in the divine carvings depicting exemplars of humility on Mount Purgatory's Terrace of Pride (Purg. X. 73-93). But, even in this longer exposition, Trajan remains an undeveloped cipher of a virtuous quality - humility. Justinian, meanwhile, speaks for himself, alluding both to achievements and failings, giving the reader an appropriately ambiguous sense of himself as a person. ${ }^{61}$

Justinian's ambiguity epitomizes the third canticle's eschatological realism. Although lower in space and therefore in justice than Trajan, he nevertheless enjoys much more narrative time, in which he develops a truly distinct voice, what Genette calls 'the generating instance of narrative discourse'. ${ }^{62}$ Clearly, his failings are essential to his status as a transitional figure between Earth and Heaven. But the necessity of such earthly and indeed sinful signifiers in communicating said transition recalls its incompatibility with remaining on Earth.

Dante's ultimate resolution of this tension is to have his first-person protagonist transcend all third-person characters, Beatrice as well as Justinian, and justify his unworthy diction by direct divine inspiration. He calls the Commedia "I poema sacro, / al quale ha posto mano e Cielo e terra' (Par. XXV. 1-2) and places at its climax a mystical vision. But assertions of privilege are insufficient to substantiate such grandiose claims: as Genette reminds us, first-person narrative is no more than '[a] story told by one of its "characters"'. 63 The poem's verisimilar characterization thus remains one of the essential guarantors of its author's exceptional poetic discretion. ${ }^{64}$ From amidst the throng of characters a coalition of voices emerges: Virgil, Brunetto, Cato, Beatrice, Cacciaguida and others. These memorable characters use their narrative authority to vouch for the pilgrim's membership in the City of God in Exile, even if they are themselves temporarily or permanently excluded from its heavenly continuation.

\section{The Canzoniere's community of blessed poets}

Although Dante could not have known it, his formation of the blessed into a mystical, corporate union presages a central issue in the beatific vision controversy that would erupt around a decade after his death. ${ }^{65}$ Pope John XXIl, a canon lawyer by training, drew on corporation theory in a way that echoes Dante's heavenly body politic, arguing that the blessed before the Last Judgment become citizens of the Regnum Christi, with Christ's humanity at its head but not the other two persons of the Trinity. ${ }^{66}$ Clearly, the Commedia does not support John's fundamental proposal that, before the resurrection of their bodies, the damned do not enter Hell and the saved do not enjoy the full vision of the Triune God. But its underlying eschatology meshes quite closely with 
compromise stances associated with Franciscan thinkers sympathetic to the renegade pope. The Franciscans proposed that the souls of the blessed would receive the beatific vision immediately upon purification but that this would be enhanced further by the resurrection of their bodies. ${ }^{67}$

With the election of Benedict XII to the Papacy in 1334, and his issuance of the constitution Benedictus Deus in 1336, John XXII's views and the more moderate Franciscan position were swept aside in favour of a Thomist assertion of saved souls' immediate and complete access to the beatific vision even before the bodily Resurrection. ${ }^{68}$ In this context, any attempt to emulate the Paradiso's detailed and verisimilar treatment of the life of the blessed before the Last Judgment became inconceivable.

Petrarch had close ties to the Papal court at Avignon in the 1330s and his letters demonstrate his familiarity with the disputes over the beatific vision. ${ }^{69}$ He even admits to sympathizing with John XXII's side of the debate, albeit accepting that 'the opinion was refuted by the more rational judgment of many'. ${ }^{70}$ Benedictus Deus's doctrine that the experiences of beatitude in time and after the Last Judgment are qualitatively equivalent is surely a significant factor in Petrarch's treatment of Paradise in his works, which is repeated and yet oblique.

Like Dante's Vita nova (c. 1294), Petrarch's Rerum vulgarium fragmenta, or Canzoniere, is a testimony of an exemplary female figure before and after her death and salvation. ${ }^{71}$ However, Petrarch respects the changed doctrinal context by maintaining a more earthly perspective, abandoning Dante's ambition to ascend to Paradise in order to praise the beloved. ${ }^{72}$ At the same time, the Canzoniere still makes use of a realist exemplarity in its repeated evocations of living, historicized contemporaries in earthly time and space. ${ }^{73}$ Beyond Laura, the Canzoniere includes poems addressed to around sixteen other historical persons - disputes over some of their identities make it impossible to give a precise number - all male friends connected to the cultural elite and most of them fellow vernacular love poets. By subtracting the now heterodox aspiration of a paradisiacal engagement with blessed characters, while maintaining the exemplarity of contemporary figures and the socio-political context, Petrarch expands on Dante's claim of spiritual authority for a realist account of sublime human love.

Especially in Part I, the Canzoniere predominantly employs effictio to describe Laura. $^{74}$ Petrarch emphasizes his beloved's physical and biographical characteristics - her blonde hair, her light-coloured eyes, her birth and upbringing near Avignon - whereas Dante's descriptions of Beatrice concentrate on her effects on the lover. ${ }^{75}$ The use of effictio flattens Laura's character and allows the first-person perspective to dominate; at the same time, it underlines her centrality to the Canzoniere's redemptive narrative and insists on the importance of the poet's encounters with his lady in historical time. After Laura's death, the poet changes course, introducing the 'narrative luxury' and 'reality effects' associated with sermocinatio and notatio to his descriptions of the beloved (see RVF 279, 302, 341, 359). These passages connect with Triumphus Mortis II, which also presents a loquacious, historicized Laura. Paradoxically, Laura's characterization becomes more realist after her death and beatification.

While Laura remains alive, notatio and sermocinatio are largely restricted to minor characters: the aged pilgrim of RVF 16, or RVF 50's Ovidian simpliciores. Instead, Petrarch moulds the topos of lontananza (distance from the beloved) into a mark of distinction. 
Again, this means a strongly thematized third-person focalization is lacking and internal dialogues within a divided poetic self, with Love for example, play the defining role of the Commedia's encounters with external, historicized subjects. ${ }^{76}$

A notable outlier is canzone 119, which connects the unfulfillable eros of the poems for Laura to fleshed-out female characters in a way other lyrics of Part I do not. Commentators have read the two ladies with whom the poet speaks as allegories of Glory and Virtue but this is not explicit in the text. In fact, the seventh stanza's explanation that they are immortal 'ombr[e]' (RVF 119. 99), could imply that they are pseudo-corporeal visitors from the Afterlife given a figural interpretation, like Virgil in Inferno I. $^{77}$ Whatever the ladies' ontological status, it is clearly significant that one of them crowns the poet with laurels - a reference to Petrarch's coronation at Rome in 1341 that granted him the powers and immunities necessary to his poetic activities. ${ }^{78}$

We saw above that the Commedia seeks authority primarily by internal means, including its characters. RVF 119, by contrast, combines 'reality effects' in characterization with reference to an external biographical event: the coronation ceremony granting Petrarch a formal status as poet (officium poetae) analogous to princely sovereignty. ${ }^{79}$ As he was no doubt aware, Petrarch's receipt of the laurels realizes on Earth an ambition expressed in Dante's Paradiso, where the laurel crown also connects poetic glory with political power. ${ }^{80}$ The documents associated with the coronation make other relevant literary theoretical claims, all of which have precedents in the Commedia: that poetry 'set[s] forth truths physical, moral and historical'; that poets are sacred figures possessed of prophetical insight whose genius is a divinely bestowed gift; and that their works may serve as spiritual inspiration and ethical guidance for others. ${ }^{81}$

While RVF 119 clearly refers to Petrarch's coronation, it also incorporates this external event into the fiction of the poem and into the Canzoniere's master narrative of conversion. Not only do this poem's third-person characters stand out in context, so does the poetic 'I', who professes his love for a lady other than Laura and dramatizes a change of heart from his first to his second immortal visitor - two things which other poems, RVF 16 for example, depict as impossible. ${ }^{82}$

The poems before and after RVF 119 help integrate its anomalies - love for ladies other than Laura and non-erotic autobiography - into the Canzoniere's amorous realism. The preceding poem, RVF 118, marks sixteen years of continuous love since the first meeting with Laura narrated in RVF 3. Before this is a sequence of ten poems, which all recount visions of Laura (RVF 108-117). Three of these poems address the fellow lyricist, Sennuccio del Bene (RVF 108, 112, 113), ${ }^{83}$ who demonstrates the poet's preceptive authority (magisterium) acknowledged in the coronation ceremony. ${ }^{84}$ As a fellow subject of 'il signor nostro Amore' (112. 14; cf. 108. 12), Sennuccio has a special moral standing that allows Petrarch to turn to him for emotional validation (112. 1-4) and advice (113. 14).

After the shades of RVF 119 return to their heavenly abode, the congedo admits that some may find the poem's meaning obscure; the poet thus promises 'ch'altro messaggio il vero / farà in più chiara voce manifesto' (108-09). RVF 120 immediately fulfils this promise by reasserting Dante's claim that poets have special knowledge of the Afterlife. This sonnet addresses another vernacular poet, Antonio Beccari, who wrote a canzone in Petrarch's memory in 1343, believing him to have died. After 
politely correcting Beccari, Petrarch claims that, like Dante, he in fact visited the Gate of Hell during a recent illness, only to see an inscription above it assuring him that it was not yet his time (120.8-12). By raising but then dismissing the possibility of his own journey through the afterlife, Petrarch implies both the authority and the greater orthodoxy of his mediated, earthly perspective.

Having demonstrated his magisterium, Petrarch returns to his central theme of love for Laura. RVF 121 is a madrigal asking Love to release Petrarch from his feelings for a single 'giovenetta donna' (121. 1) whose physical traits and aloof demeanour resemble Laura, ${ }^{85}$ an impression RVF 122 seems to confirm with its commemoration of the seventeenth anniversary of the first encounter. RVF 123 then describes Laura as a heavenly, angelic figure, reminiscent of the beloved in Guinizzelli and Dante's early lyrics, and also of the two ladies of RVF 119. The final lines hint that a risen, glorified Laura may join the dialogue with the poet: 'et tacendo dicea, come a me parve / "Chi m'allontana il mio fedele amico?"' Of course, this is exactly what the departed Laura does in the Trionfi and Part II of the Canzoniere.

When the Canzoniere comes to record Laura's death, a historicized male friend, again Sennuccio del Bene, plays a key role in defining the possibilities for contact between the lover and his now departed beloved. In a postil to a draft of 'Che debb'io far? Che mi consigli amore' (RVF 268), the great lament poem for Laura, Petrarch records how he first heard of Sennuccio's death, a little over a year after Laura's. The news caused him to revise the canzone's congedo, addressed to his friend. ${ }^{86}$

The draft congedo reverses the situation of Sennuccio's canzone 'Quella speranza, che-mmi fe' lontano', addressed to a beloved in Florence after the poet had gone into exile to join Henry VII's doomed Italian campaign (1310-13). ${ }^{87}$ Sennuccio's congedo begins 'Canzon, tu.nne girai ritta in Toscana / a quel piacer che mai non fu piu fino'. ${ }^{88}$ Petrarch's draft also directs his poem to Tuscany - specifically to Florence - to seek out not a lady but Sennuccio, who has at last returned home in body, albeit his exiled spirit still wanders elsewhere.

S'Amor vivo è nel mondo

e ne l'amicho nostro al qual tu vai,

canzon, tu 'I troverai

mezzo dentro in Fiorenza e mezzo fori:

altri non v'è che 'ntenda i miei dolori. ${ }^{89}$

In place of the draft congedo, Petrarch wrote the sonnets 'Oimè il bel viso, oimè il soave sguardo' (RVF 267) and 'Sennuccio mio ben che doglioso et solo' (RVF 287). In the Canzoniere, the former poem announces Laura's death. The lament for Sennuccio, meanwhile, comes after the first sequence of apparitions and dream visions of Laura's departed soul (RVF 279-86) - a revival of the themes of RVF 108-19.

As he addresses Sennuccio for the final time, Petrarch expresses certainty that his friend's soul has risen to Heaven. Moreover, he gives one of the Canzoniere's few detailed treatments of the state of the blessed after death. ${ }^{90}$ Drawing again on his poetic magisterium, Petrarch places Sennuccio in the third heaven: that of Venus and also the heaven that the Apostle Paul visited (2 Cor. 12: 2). RVF 287 further populates this sphere with the soul of Laura and those of other vernacular love poets, including Cino and Dante. Laura's elevation to the Third Heaven (reiterated at RVF 302. 3) thus 
unites the beloved in salvation with characters representing the lover. In so doing, the poem promises fulfilment of the dream of eternal union in Paradise of poet and lady that had fascinated Italian lyric love poets since Giacomo da Lentini. ${ }^{91}$

Despite these positive vernacular echoes, RVF 287 raises problematic theological issues. In the Paradiso, the Third Heaven is the location to which Rahab is said to have ascended before other souls: 'Da questo cielo, in cui l'ombra s'appunta / che II vostro mondo face, pria ch'altr'alma / del trïunfo di Cristo fu assunta' (Par. IX. 117-20). Commentators since lacomo della Lana have inferred that Rahab was 'in Venus poetically', 92 since her true abode is surely the Empyrean. However, this is not made explicit in the text. The Canzoniere contains an analogous ambiguity between orthodoxy (Empyrean) and poetic licence (Third Heaven) when Laura descends to console Petrarch in the canzone 'Quando il soave mio fido conforto' (RVF 359). In the collection's most extensive application of notatio and sermocinatio to Laura, the beloved contradicts the poet's apparently authoritative descriptions of the Third Heaven and declares that she has come 'dal sereno / ciel Empireo' (9-10).

The uncertain heavenly abode of Rahab and Laura in Heaven evokes a key text in the beatific vision controversy: book 12 of Augustine's De Genesi ad litteram, which casts doubt on the possibility of distinguishing between the Third Heaven (2 Cor. 12: 2) and the Celestial Paradise (2 Cor. 12: 4) as the place to which the Apostle Paul ascended. ${ }^{93}$ The two poets' depictions of Heaven reflect the exegetical principles that Augustine expounds here: the subordination of details to the search for higher truth and the acceptance of apparent imprecisions as the inevitable result of contemplating the ineffable from a limited human perspective. ${ }^{94}$

Like the Bible, the Paradiso supplies a mass of details that make any tensions or contradictions easier to discount. But the Canzoniere describes salvation only sporadically and the inconsistency between RVF 287 and 302, and RVF 359 is thus more overt. In truth, Lana's analysis of Paradiso IX seems to fit Petrarch better than Dante. Given Petrarch's reluctant acceptance of Benedictus Deus, he seems to allow himself a 'poetical' placement of souls in his own voice, applying especially to fellow poets and the beloved, with a reversion to orthodoxy when Laura herself voices her salvation. Where Dante's eschatological realism aspires to an impossible plenitude through layers of detail, Petrarch's emphasizes the gaps and incompleteness that are the counterpart of such descriptive richness. ${ }^{95}$

\section{The Triumphi and the limits of salvific characterization}

One could say that Petrarch's Triumphi sit at the apex of a triangle, the other two corners of which are the Canzoniere and Commedia. Petrarch's long poem draws its form, its narrative frame and much of its diction from its Dantean predecessor. Moreover, the title of Petrarch's poem appropriates the transumptio of the triumph that underlies Paradiso's eschatological realism. Equally, the love story with Laura is central, as in the Canzonierie, albeit the antiquarian concerns of the poet's Latin works find more space in the Triumphi. ${ }^{96}$

As in the Commedia, the third-person characters whom the protagonist meets are souls detached from their bodies. Petrarch avoids explaining how they manifest themselves to his mortal senses by framing the Triumphi as a dream vision (TC I. 7-12). Moreover, his 
dream occurs just before dawn, the hour when such visions were believed to be most prophetic. $^{97}$ Nonetheless, Petrarch's souls are grouped by earthly concerns - love, chastity, fame - without regard for their fates in Christian eschatology.

The significance of this hybrid setting, part historical, part transcendent, emerges especially clearly when the protagonist encounters characters from the Commedia. For example, as in Inferno $\mathrm{V}$, one sequence of notable lovers from the past ends on the modern pair Paolo Malatesta and Francesca da Rimini (TC III. 12-84). In an apparent allusion to Dante's Paolo and his damnation, the pair are weeping. ${ }^{98}$ However, only a handful of Petrarch's list of famous lovers - Semiramis and Tristan, for example appear among Dante's lustful; indeed, according to the Commedia, many are saved including David, Jacob, Solomon, Judith. Instead of Inferno V's tragic counterpoint between uncontrolled human love and divine charity Triumphus Cupidinis III suspends judgment on its lovers' eternal fate and foregrounds the continued humanity of the departed. The Triumphus Pudicitiae reiterates these themes: it attacks Inferno V's condemnation of Dido for lust as ignorant chatter of the mob (TP, 157-9); then the very next tercet rejects Paradiso III's account of Piccarda Donati's coerced marriage as a desertion of holy vows and praises her attempts to defend her chastity (TP, 160-62).

The Triumphi overturn the characterization practices of the Commedia and of the Canzoniere: the poem employs effictio to evoke the overwhelming majority of its characters, reserving notatio and sermocinatio for a few notables, especially Laura. The concision of effictio leaves no space to confirm the eternal abode of several characters whose salvation the Canzoniere asserts unequivocally - Cino, Dante, Guittone d'Arezzo, Sennuccio, and Francesco degli Albizzi. ${ }^{99}$ The only person in the poem assured of salvation is Laura, who also takes responsibility for Petrarch's coronation by wresting his laurels from Love's grasp (TP, 91-96) and ferrying them to Rome's Capitoline Hill (TP, 178-86). The vision of Laura in the Triumphi thus reflects and expands on that of $R V F$ 359, where she also bears 'un ramoscel di palma / et un di lauro' (7-8). Together, these visions suggest that only a blessed intermediary can impart truths about salvation. Mutatis mutandis, they imply the poetic nature of other descriptions of Heaven: in the Canzoniere and the Paradiso.

The uncertainty over the fate of Petrarch's characters is also relevant to his choice of the triumph as his work's titular metaphor. For Dante, the triumph could open a fragile but real conduit between Earth and Heaven but Petrarch's triumphs belong either to this world or to the next.

Questi triumfi, i cinque in terra giuso

avem veduto, et a la fina il sesto,

Dio permettente, vederem lassuso.

(TE, 121-23)

The common understanding of the Triumphi as an earthly, humanistic celebration might therefore appear valid, at least for the first five triumphs. ${ }^{100}$ However, the deep integration of the Roman triumph into Christian iconography remains relevant. ${ }^{101}$ Love's chariot (TP, 16-23), for example, has clear Christological connotations, as did Beatrice's in Dante's Earthly Paradise. The battle in the Triumphus Pudicitiae between Love and the personified female Virtues draws on a tradition of Christian allegory beginning with Prudentius's Psychomachia (c. 405). But where the Paradiso proposes the 
triumph as an earthly manifestation of the Universal Church, in the Triumphi the earthly glory that the poet justly accrues requires a personal mediator to connect it to its heavenly counterpart.

The eschatological realist love narrative thus governs the progression of Petrarch's poem all the way to its culmination, whereas Dante's pilgrim goes beyond Beatrice at the end of the Commedia. From desire for Laura in the Triumphus Cupidinis, we move to the glory of her chastity in the Triumphus Pudicitiae. The Triumphus Temporis, which refutes the pseudo-immortality of earthly fame on which Petrarch's poet figure depends, is a dialogue with the sun, one of the poet's key metonyms for his beloved. ${ }^{102}$ And, at the heart of the sequence, is the Triumphus Mortis, which establishes Laura's salvation - the single point of eschatological certainty in the poem.

Following the new doctrine that minimized the distinction between salvation in spirit and in body, Petrarch does not qualify or analyse the beatitude to which Laura is headed. Moreover, the Laura of the Triumphi is a complex character who offers greater insight into her feelings and her agency in the love narrative than anywhere else in Petrarch's work. This fully adumbrated Laura legitimates Petrarch's poetic project by confirming that his officium poetae is fully compatible with Christian salvation, including the apparently secular, antiquarian interests of the Triumphus Fame and the Latin works.

Finally, in the Triumphus Eternitatis, Petrarch dreams of the glory his verses will bring, to him and Laura, when he joins her in Heaven.

E vedrassi ove, Amor, tu mi legasti

ond'io a dito ne sarò mostrato:

'Ecco chi pianse sempre, e nel suo pianto

sovra 'I riso d'ogni altro fu beato!'

E quella di ch'ancor piangendo canto

avrà gran maraviglia di se stessa,

vedendo si fra tutte dar il vanto.

(TE, 93-99)

Petrarch's celestial triumph combines the 'poetical' vision of RVF 287 with the orthodoxy of RVF 359: not only does the interpersonal connection with the beloved continue in Heaven, it makes Petrarch's hoped-for beatitude particular and indivisible. While the Commedia's panoply of personae cannot subsist in Petrarch's unitary Heaven, one instance of realist characterization remains indispensable.

\section{Conclusion}

Because of the new teaching that the saved proceed directly to the full enjoyment of the beatific vision, Petrarch's engagement with the Afterlife is circumspect. But even as he discards, and implicitly critiques, Dante's attempt at a verisimilar representation of the Hereafter, Petrarch retains and enhances his precursor's central claim that amorous vernacular verse can glorify the beloved, even in Heaven. The realist core of both writers' poetics is this belief in the rectitude of poetry dedicated to a historical lady. In a modern context, especially after the rise of Italian nationalism, such faith in the value of literary authorship has been read as idealistic, especially in Petrarch's case. In truth it is 
a Christian vision of learned discipleship and instruction (magisterium) applied to nonecclesiastical writings by careful use of contemporary rhetorical, legal and theological precepts that foreshadow later narrative realism.

\section{Notes}

1. 'At its center, the poem reveals its analogy to the structure of history [...]. The fiction of the Divine Comedy is that it is not fiction', Charles S. Singleton, Dante Studies I: Commedia, Elements of Structure (Cambridge, MA: Harvard University Press 1954), pp. 61-62.

2. Petrarch, Letters on Familiar Matters, trans. Aldo S. Bernardo, 4 vols (Albany: State University of New York Press), I, 102 (Familiares II. 9); for original, see Petrarch, Le familiari, ed. by Vittorio Rossi, 3 vols (Florence: Sansoni, 1933-37; repr. 1968) I, 90-97 (p. 94).

3. 'The fourteenth-century commentators are unanimous [...] on the fictionality of Dante's invention', Michael Caesar, Introduction [1989], in Dante: The Critical Heritage (London: Routledge, 2010), pp. 1-87 (p. 8).

4. Umberto Bosco, Francesco Petrarca, rev. edn (Bari: Laterza, 1961) pp. 7-8.

5. Gianfranco Contini, 'Preliminari sulla lingua del Petrarca [1951]', in Petrarch, Canzoniere, ed. by Contini (Turin: Einaudi, 1964), pp. vii-xxxv.

6. Compare Georg Lukács, 'Reportage or Portrayal?', in Essays on Realism, ed. by Rodney Livingstone (Cambridge, MA: MIT Press, 1981), pp. 45-75.

7. 'Realism is a position that attributes to the object or state of affairs represented a status independent of representation itself', Ruth Ronen, 'Realism, Theories of', in Routledge Encyclopedia of Narrative Theory, <http://www.routledgeonline.com:80/literature/Book.aspx? id=w495> [accessed 7 November 2017], §3.

8. Roland Barthes, 'The Reality Effect', in The Rustle of Language, trans. by Richard Howard (Oxford: Blackwell, 1986), pp. 141-48; Jacques Le Goff, 'Intérêt historique', in Claude Bremond, Le Goff and Jean-Claude Schmitt, L"exemplum', Typologie des sources du Moyen Âge occidental, 40, rev. edn (Turnhout: Brepols, 1996), pp. 79-84 (p. 80). All translations are mine unless a published English version is cited.

9. Philippe Hamon, Le Personnel du roman: Le Système des personnages dans le 'Rougon-Macquart' d'Émile Zola (Paris: Droz, 1983), pp. 28-29, emphasis in original.

10. Respectively, veri similis narratio ('plausible statement of facts'); demonstratio ('ocular demonstration'); argumentum ('realistic narrative'): see [anon.], Rhetorica ad Herennium, trans. by Harry Caplan (Cambridge, MA: Harvard University Press, 1954), p. 28 (I. 16); pp. 404-08 (IV. 55); p. 24 (I. 13).

11. Virginia Cox, 'Ciceronian Rhetoric in Late Medieval Italy', in The Rhetoric of Cicero in its Medieval and Early Renaissance Commentary Tradition, ed. by Cox and John O. Ward (Leiden: Brill, 2006), pp. 109-43.

12. Rhetorica ad Herennium, p. 386 (IV. 49). Cf. Bono Giamboni, Fiore di rettorica, ed. by Gian Battista Speroni (Pavia: University of Pavia, 1992), p. 45 (\$45); Brunetto Latini, Trésor, ed. by Pietro Beltrami and others (Turin: Einaudi, 1997), p. 664 (III. 13).

13. Giamboni, Fiore di rettorica, p. 49 (§46). Cf. Rhetorica ad Herennium, pp. 386-90 (IV. 50).

14. Giamboni, Fiore di rettorica, p. 51 (§48). Cf. Rhetorica ad Herennium, pp. 394-98 (IV. 52).

15. See trespas (digression) and demonstrance (characterization), in Latini, Tresor, pp. 664, 666 (III. 13. 9-11).

16. Barthes, 'Reality Effect', p. 141, emphasis in the original. Barthes's term for Flaubert's descriptions, 'insignificant notation[s]', echoes the classical rhetorical term notatio (p. 142), for which see n. 13.

17. See Philippe Hamon, 'Pour un statut sémiologique du personnage', in Roland Barthes and others, La Poétique du récit (Paris: Seuil, 1977), pp. 115-80; Uri Margolin, 'Characters and their Versions', in Fiction updated: Theories of fictionality, narratology, and poetics, ed. by Calin-Andrei Mihailescu and Walid Hamarneh (Toronto: University of Toronto Press, 1996), 
pp. 112-32; Catherine Gallagher, 'What Would Napoleon Do? Historical, Fictional, and Counterfactual Characters', New Literary History, 42 (2011), 315-36.

18. See Bremond, Le Goff, Schmitt, L'exemplum', pp. 80-82; Jacques Le Goff, 'L'exemplum et la rhétorique de la prédication aux XIIle et XVle siècles', in Retorica e poetica tra XII e XIV secolo (Florence: La Nuova Italia, 1988), pp. 3-29.

19. Giamboni, Fiore di rettorica, p. 44 (\$43). Cf. Rhetorica ad Herennium, IV. 49 (pp. 382-84).

20. Jacques LeGoff, The Medieval Imagination, trans. by Arthur Goldhammer (Chicago, IL: University of Chicago Press, 1988), p. 78. See also Carlo Delcorno, Exemplum e letteratura (Bologna: Il Mulino, 1989).

21. E.g. 'And, in order that the master [sc. Brunetto] may more clearly explain what he has just said, he will give a few ancient examples of great authority', Trésor, p. 688 (III. 34). There follows a debate between Cicero, Caesar and Cato that draws heavily on Sallust's Bellum Catilinae.

22. Le Goff, Medieval Imagination, p. 79.

23. Recent studies of Dante and preaching with bibliography include: Zane Mackin, 'Dante, the Rhetoric of Crisis, and Vigilante Preaching', Annali d'italianistica, 34 (2016), 31-56; Niccolò Maldina, 'Dante e l'immagine del buon predicatore nel Paradiso', L'Alighieri, 43 (2014), 41 64; George Ferzoco, 'Dante and the Context of Medieval Preaching', in Reviewing Dante's Theology, ed. by Claire Honess and Matthew Treherne, 2 vols (Oxford: Peter Lang, 2013), II, 187-210.

24. Delcorno, Exemplum e letteratura, p. 197. For the coexistence of 'piacere, racconto, esemplarità e conoscenza' in the Novellino (c. 1290), see Gianluca Briguglia, 'Il diletto della lingua: La scelta della lingua come spazio politico in alcuni testi politici e letterari della seconda metà del Duecento', in Thinking Politics in the Vernacular from the Middle Ages to the Renaissance, ed. by Briguglia and Thomas Ricklin (Freiburg: Academic Press, 2011), pp. 43-56 (p. 55).

25. 'The most impressive and fertile innovation which Dante's genius incorporated into the antique and medieval heritage [is] his drawing upon contemporary history', Ernst Robert Curtius, European Literature and the Latin Middle Ages [1948], trans. by Willard R. Trask (New York: Harper \& Row, 1963), p. 365.

26. Petrarch, Trionfi, Rime estravaganti, Codice degli abbozzi, ed. by Vinicio Pacca and Laura Paolino (Milan: Mondadori, 1996), p. 62 (Triumphus Cupidinis, I. 44-45).

27. 'For the corporeal word [i.e. one referring to concrete, familiar events], passes more easily from hearing to imagination and from imagination to memory', Stephen of Bourbon, Tractatus de diversis materiis predicabilibus, ed. by Jacques Berlioz, 3 vols (Turnhout: Brepols, 2002-15), I, 4. And see Delcorno, Exemplum e letteratura, pp. 10-11.

28. Cf. Par. XVII. 135-41; and see Maria Cecilia Bertolani, Il corpo glorioso: Studi sui 'Trionfi' di Petrarca (Rome: Carocci, 2001), pp. 85-88.

29. Quotations from the Commedia follow the text of La commedia secondo l'antica vulgata, ed. by Giorgio Petrocchi, 4 vols (Florence: Le Lettere, 1994).

30. Laurence E. Hooper, 'Characterization', in The Cambridge Companion to Dante's 'Commedia', ed. by Zygmunt G. Barański and Simon Gilson (Cambridge: Cambridge University Press, forthcoming).

31. Ibid.

32. Ibid.

33. See Caroline Walker Bynum, 'Somatomorphic Soul and Visio Dei: The beatific vision Controversy and its Background', in The Resurrection of the Body in Western Christianity 2001336 (New York: Columbia University Press, 1995), pp. 289-317. Etienne Gilson's essay, 'Dante's Notion of a Shade: Purgatorio XXV', Mediaeval Studies, 25 (1967), 124-42 remains a useful introduction.

34. Baldus calls this a 'uniting fiction [fictio unitiva], which feigns that two days are one [...], which makes fathers and sons into one body', Baldus Ubaldi, In Secundam Digesti Veteris partem Commentaria (Venice: Giunta, 1586), fol. $187^{r}$ (on Digest XXIII. 2. 57).

35. See William Courtenay, Capacity and Volition: A History of the Distinction of Absolute and Ordained Power (Bergamo: Lubrina, 1990). 
36. Cf. 'The default world of the novel is ours [...]. Realist novelistic characters [...] cannot do anything that would alter the world in such a way as to make it inconsistent with our own'. Catherine Gallagher, 'What Would Napoleon Do?', p. 334.

37. 'A [legal] fiction takes as true what is certainly contrary to the truth [...]. Although what it feigns may be contrary to the truth, it cannot be impossible by nature', Cino da Pistoia, In Codicem et aliquot titulos primi Pandectorum tomi [...] Commentaria (Frankfurt: Feyerabendt, 1578), fol. 212v (on Codex IV. 19. 16); and see Yan Thomas, 'Les artifices de la vérité en droit commun médiéval', L'Homme, 175-76, no. 3-4 (2005), 113-30 (pp. 127-29).

38. Of course, we are unsure whether the Paradiso reports a bodily or a spiritual ascent: see Par. I. 73-75. Even so, evocations of corporeality, like the pilgrim's temporary blindness in cantos $X X V$ and XXVI, imply at least some validity of physical science in its interpretation. For bibliography on the body in Paradiso, see Manuele Gragnolati, Experiencing the Afterlife: Soul and Body in Dante and Medieval Culture (Notre Dame, IN: University of Notre Dame Press, 2005), pp. 152-78, 245-50.

39. For the problem of representing time and movement in the Paradiso, see Teodolinda Barolini, 'Paradiso: Dante's Heaven of the Sun as a Meditation on Narrative', in The Undivine 'Comedy': Detheologizing Dante (Princeton, NJ: Princeton University Press, 1992) pp. 194-217

40. Cf. Beatrice's explanation of moon spots: the 'body' of the Moon, also made of aether, appears darker in places that possess a 'virtù diversa', which, like the union of (aethereal) body and soul, individuates its different parts: Par. II. 133-48.

41. 'E sì come ciascuno a noi venìa, / vedeasi l'ombra piena di letizia / nel folgór chiaro che di lei uscia' (Par. V. 106-08).

42. For heavenly physics, see Patrick Boyde, Dante Philomythes and Philosopher: Man in the Cosmos (Cambridge: Cambridge University Press, 1981), pp. 132-41.

43. 'Sì che 'I tuo cor quantunque può giocondo / s'appresenti a la turba trïumfante / che lieta vien per questo etera tondo', Par. XXII. 130-32; 'In su vid' io così l'etera adorno / farsi e fioccar di vapor trïunfanti', XXVII. 69-70.

44. Par. XXXII. 67-75. Compare Nessus's identification of the tyrant Ezzelino da Romano by his dark hair, while his neighbour, Opizzo d'Este, is blond (Inf. XII. 109-11).

45. See Joseph Canning, 'Law, Sovereignty and Corporation Theory, 1300-1450', in The Cambridge History of Medieval Political Thought: C. 350-c. 1450, ed. by J. H. Burns (Cambridge: Cambridge University Press, 1988), pp. 454-76. The failure to account for Paradiso's use of corporation theory has led some scholars to the untenable conclusion that 'Dante the poet [...] give[s] Dante the traveler a glimpse of the risen and glorified body [of saved souls other than Mary] even before the end of time', Bynum, Resurrection of the Body, pp. 302-03; see also Anna Maria Chiavacci Leonardi "'Le bianche stole": Il tema della Resurrezione nel Paradiso', in Dante e la Bibbia, ed. by Giovanni Barblan (Florence: Olschki, 1988), pp. $249-71$ (pp. 26970); Gragnolati, Experiencing the Afterlife, pp. 161-78. See further below, n. 68.

46. Michael Wilks, 'Societas Christiana', in The Problem of Sovereignty in the Later Middle Ages: The Papal Monarchy with Augustinus Triumphus and the Publicists (Cambridge: Cambridge University Press, 1963), pp. 15-64 (p. 21).

47. For the Church as corpus mysticum, see Henri de Lubac, Corpus Mysticum: The Eucharist and the Church in the Middle Ages [1949] (Notre Dame, IN: University of Notre Dame Press, 2007), esp. pp. 75-119. For the overlap between corporation theory and ecclesiology, see Melchiorre Roberti, 'Il corpus mysticum nella storia della persona giuridica', in Studi di storia e diritto in onore di Enrico Besta, 4 vols (Milan: Giuffrè, 1937-39), IV, 39-88.

48. Beatrice calls the congregation of the blessed 'nostra città' and 'foro divino' (Par. XXX. 130, 142); Dante compares his stupefaction on glimpsing the Heavenly Rose to some barbarians encountering the architectural marvels of Rome (XXXI. 31-40); meanwhile, his wonder at St Bernard's 'vivace / carità' is like a Croatian pilgrim visiting St Peter's to view the Veronica (103-11); Bernard talks of ' $\mathrm{i}$ gran patrici / di questo imperio giustissimo e pio' (XXXII. 11617). And compare Claire E. Honess, From Florence to the Heavenly City: Poetry and Citizenship in Dante, pp. 57-61 
49. For poetic uses of sylvan citizenship and bibliography, see Laurence Hooper, 'Exile and Petrarch's Reinvention of Authorship', Renaissance Quarterly, 69 (2016), 1217-56 (p. 1228).

50. For the transactional quality of Trecento naturalization, see Julius Kirshner, 'Civitas sibi faciat civem: Bartolus of Sassoferrato's Doctrine on the Making of a Citizen', Speculum, 48 (1973), 694-713 (pp. 707-111).

51. For transumptio in Dante and bibliography, see Laurence Hooper, 'Dante's Convivio, Book 1: Metaphor, Exile, Epochē', MLN, 127, no. 5, Supplement (2012), S86-S104 (pp. S91-S94).

52. On the ancient triumph, see Mary Beard, The Roman Triumph (Cambridge, MA: Belknap Press, 2007). For its Christian and medieval reception, see Antonio Pinelli, 'Feste e trionfi: Continuità e metamorfosi di un tema', in Memoria dell'antico nell'arte italiana, ed. by Salvatore Settis, 3 vols (Turin: Einaudi, 1984-86), II: I generi e i temi ritrovati (1985), 279-350.

53. Compare the allusions to the Heavenly Jerusalem discussed in Honess, From Florence, pp. 10750 , which remain on a purely 'tropological level' (p. 118).

54. See Pinelli, 'Feste e trionfi'.

55. The adjective 'triumfale' is applied exclusively to Beatrice's chariot (Purg. XXIX. 107; Purg. XXXII. 118-19), which is also called a 'basterna' (Purg. XXX. 16): 'a cart, festooned with veils, found in Gaul, where it was used to transport chaste matrons to sacred festivals', Robert Hollander in Dante, Purgatorio, trans. by Robert and Jean Hollander (New York: Anchor Books, 2003), p. 678 (on Purg. XXX. 16).

56. Alessandro Benucci, 'La processione santa di Paradiso XXIII: Trionfo classico o visione mistica?', in Ortodossia ed eterodossia in Dante Alighieri, ed. by Carlota Cattermole, Celia de Aldama, Chiara Giordano (Madrid: Ediciones de La Discreta, 2014), pp. 361-78. Benucci mentions only Ascension iconography but the pilgrim's inability to gaze on the luminous figures of Beatrice and Christ clearly alludes to the Transfiguration. See, for example, Duccio, The Transfiguration, from Maestà, 1308-11, gold and tempera on wood, National Gallery, London.

57. Uniquely, Justinian refers both to the triumph in its Christianized sense when he greets Dante as a living man who will see 'li troni / del trïunfo etternal' (Par. V. 115-117), and in its historical one, when he mentions Scipio and Pompey's triumphs (VI. 52-53).

58. Corpus iuris civilis, ed by Paul Krueger and others, 3 vols (Berlin: Weidmann, 1872-92), I, xiii (De conceptione Digestorum).

59. Ibid.

60. Gordon Whatley rightly notes that Dante significantly reduces the role of Gregory the Great compared to other versions of the Trajan legend: 'The Uses of Hagiography: The Legend of Pope Gregory and the Emperor Trajan in the Middle Ages', Viator 15 (1984), 25-63 (pp. 4350). However, none of the descriptions of Trajan invites an affective identification equivalent to Gregory's wry chuckle at his own faulty understanding of the celestial hierarchy in Par. XXVIII.

61. See Par. VI. 10-21, 112-20.

62. Gérard Genette, Narrative Discourse (Ithaca, NY: Cornell University Press, 1980), p. 213.

63. Ibid., p. 244.

64. See 'Beyond the Law: Arbitrium', in Justin Steinberg, Dante and the Limits of the Law (Chicago, IL: University of Chicago Press, 2013), pp. 53-88.

65. See Christian Trottmann, La Vision béatifique: Des disputes scolastiques à sa définition par Benoît XII (Rome: École française de Rome, 1995), esp. pp. 411-70.

66. 'The souls of the Saints abide away from any sensation of suffering and the toils of this world. But they abide in Heaven under the humanity of Christ. Nor can they see the essence of God, which they will behold only after the resurrection [of their bodies]', Pope John XXII in Marc Dymans, ed., Les Sermons de Jean XXII sur la vision béatique (Rome: Gregorian University Press, 1973), p. 142 (Sermon of 15 December 1331). And see Andrea Tabarroni, 'Visio beatifica e Regnum Christi nell'escatologia di Giovanni XXII', in La cattura della fine: Variazioni dell'escatologia in regime di cristianità, ed. by Giuseppe Rugieri (Genoa: Marietti, 1992), pp. 125-49 (pp. 142-49).

67. See Tabarroni, 'Visio beatifica e Regnum Christi'; Trottmann, Vision béatifique, pp. 524-53. 
68. See Trottmann, Vision béatifique, pp. 745-811. For the view that the Paradiso in fact upholds a Thomist view of the beatific vision close to Benedict XII's, see Tabarrroni, 'Visio beatifica e Regnum Christi', pp. 127-28. (See also Paolo Fedrigotti, 'Esprimere l'inesprimibile: La concezione dantesca della beatitudine', Divus Thomas, 52, no. 1 (2009), 17-193; Tamara Pollack, 'Light, Love and Joy in Dante's Doctrine of Beatitude', in Reviewing Dante's Theology, ed, by Honess and Treherne, I, 263-319.) But this reading ignores the poem's repeated statements that the pilgrim witnesses blessings and punishments distinct from and less than the eternal experiences of resurrected bodies: for example, Inf. VI. 103-11; Par. XIV. 37-66; Par. XXV. 122-29.

69. See Letter II. 12, in Petrarch, Familiares, trans. by Bernardo, I, 110-11; Le familiari, ed. by Rossi I, 99-101; and Letter IV. 2, in Familiares, trans. by Bernardo, I, 181-84; Le familiari, ed. by Rossi, I, 161-64. Maria Cecilia Bertolani collates and analyzes these and other sources in Petrarca e la visione dell'eterno (Bologna: II Mulino, 2005).

70. Petrarch, Familiares, trans. by Bernardo, I, 111 (II. 12); Le familiari, ed. by Rossi, I, 101.

71. The text of the Canzoniere (cited as RVF) will be quoted from Petrarch, Rerum Vulgarium Fragmenta, ed. by Giuseppe Savoca (Florence: Olschki, 2008).

72. See Franco Suitner on "quel tanto di "terrestrità" in più che Laura presenta nei confronti di Beatrice': 'Le rime del Petrarca e l'idea della donna "beatrice": Convenzioni letterarie e realtà psicologica', in Beatrice nell'opera di Dante e nella memoria europea 1290-1990, ed. by Maria Picchio Simonelli (Fiesole: Cadmo, 1994), pp. 261-78 (p. 262).

73. '[In the Canzoniere], there is an attempt to inject a kind of realism into the total picture. By making recurrent references to specific dates that recall meetings, anniversaries [...] the poet does create the impression of a personal diary', Aldo S. Bernardo, Petrarch, Laura, and the 'Triumphs' (Albany: State University of New York Press, 1974), p. 15.

74. Mariarosa Spinetti, 'Beatrice e Laura: Due mondi a confronto', in Beatrice nell'opera di Dante, ed. by Simonelli, pp. 279-91, (p. 288).

75. See Spinetti, 'Beatrice e Laura', pp. 281-85.

76. Hooper, 'Petrarch's Reinvention of Authorship', pp. 1233-38.

77. "'Miserere di me," gridai a lui, / "qual che tu sii, od ombra od omo certo!"' (Inf. I. 65-66); and see Andrew Hui, 'Dante's Book of Shadows: Ombra in the Divine Comedy', Dante Studies, 134 (2016) pp. 195-224 (pp. 198-202).

78. Hooper, 'Petrarch's Reinvention of Authorship', 1225-33.

79. See Ernst Kantorowicz, 'The Sovereignty of the Artist: A Note on Legal Maxims and Renaissance Theory of Art', in Selected Studies (Locust Valley, NY: Augustin, 1965) pp. 352-65. See also Joseph Canning on the prince's dignitas as an undying corporation, which he can delegate to officeholders: The Political Thought of Baldus de Ubaldis (Cambridge: Cambridge University Press, 1987), pp. 86-92, pp. 209-27.

80. 'Vedra'mi al piè del tuo diletto legno / venire, e coronarmi de le foglie / che la materia e tu mi farai degno. / Sì rade volte, padre, se ne coglie / per trïunfare o cesare o poeta, / colpa e vergogna de I'umane voglie' (Par. I. 25-30). See also Par. XXV. 1-9.

81. Ernest Hatch Wilkins, trans., 'Petrarch's Coronation Oration', in Studies in the Life and Works of Petrarch (Cambridge, MA: Medieval Academy of America, 1955) pp. 300-313 (pp. 307; pp. 310$11 ;$ p. 306).

82. For the change of heart in Petrarch and Dante, see Justin Steinberg, 'Dante estravagante, Petrarca disperso, and the Spectre of the Other Woman', in Petrarch and Dante: AntiDantism, Metaphysics, Tradition, ed. by Theodore Cachey and Zygmunt Barański (Notre Dame, IN: University of Notre Dame Press, 2009), pp. 263-89

83. For Petrarch's poems to Sennuccio, the most frequent addressee in the collection after Laura, see Joseph Barber, 'Il sonetto CXIII e gli altri sonetti a Sennuccio', Lectura Petrarce, 2 (1982), 21-39.

84. For the grant of magisterium, see 'Petracas Privilegium laureationis', ed. by Dieter Mertens, in Litterae Medii Aevi: Festschrift für Johanne Autenrieth zu ihrem 65. Geburtstag, ed. by Michael Borgolte and Herrad Spilling (Sigmaringen: Thorbecke, 1988), pp. 225-47 (pp. 243-46). For the use of magister and derived terms to indicate the licentia docendi (permission to teach), see Olga Weijers, 'L'appellation des professeurs au XIII' siècle', in Sine invidia communico: 
Optstellen Aangeboden an Prof. A. J. de Groot (Nijmegen: Gerard Noordt Instituut, 1985), pp. 303-20 (pp. 303-07).

85. 'Or vedi Amor, che giovenetta donna' enters the Canzoniere late in its redaction history. The previous poem 121 was the ballata 'Donna mi vène spesso ne la mente' (Petrarch, Trionfi, Rime estravaganti, p. 729), which recapitulates the change-of-heart theme while obscuring both the identities of the ladies and whether the poet does indeed transfer his love. Its inclusion would thus have complicated the narrative of return identified here but without changing its outcome.

86. Petrarch, Trionfi, Rime estravaganti, p. 850 (Codice degli abbozzi, fol. 12v).

87. Daniele Piccini, ed., Un amico del Petrarca: Sennuccio del Bene e le sue rime (Padua: Antenore, 2014), pp. 19-33.

88. Ibid., p. 32.

89. Petrarch, Trionfi, Rime estravaganti, p. 856 (Codice degli abbozzi, fol. 14').

90. See also RVF 302, 346.

91. See the sonnet 'lo m'aggio posto nel core a Dio servire', in I poeti della scuola siciliana, ed. by Roberto Antonelli, Rosario Coluccia, Costanzo Di Girolamo, 3 vols (Milan: Mondadori, 2008), I, 464.

92. lacomo della Lana, Commento alla 'Commedia', ed. M. Volpi with A. Terzi, 4 vols (Rome: Salerno, 2009), III, 1978 (on Par. IX. 118).

93. 'But we are not going rashly to assert either that Paradise is in the third heaven, or that he was snatched up first to the third heaven and then again from there into Paradise', Augustine, On Genesis, trans. by Edmund Hill, O.P. (New York: New City Press, 2002), p. 503 (De Genesi ad litteram XII. 34. 65). For Augustine's importance to the beatific vision controversy, see Trottmann, Vision béatifique, pp. 54-67.

94. See Michael Cameron, 'Augustine and Scripture', in The Blackwell Companion to Augustine, ed. by Mark Vessey (Oxford: Wiley-Blackwell, 2012), pp. 200-14.

95. 'In other words, the very absence of the signified, to the advantage of the referent alone, becomes the very signifier of realism', Barthes, 'Reality Effect', p. 148.

96. The out-of-place appearance of Scipio Africanus in the Triumphus Pudicitiae - "I triumpho non suo' $(T P, 175)$ - epitomizes the place of the classics in the poem. For the parallels between Laura and Scipio, see Bernardo, Petrarch, Laura, and the 'Triumphs', pp. 98-100. The text of the Triumphi comes from Petrarch, Trionfi, Rime estravaganti, with Triumphus Cupidinis I cited as TC I, and so on.

97. See Robert Durling and Ronald Martinez in Dante, Purgatorio, trans. by Robert Durling (Oxford: Oxford University Press, 2003), p. 151 (on Purg. IX. 13-18).

98. See TC IV. 83-84, and cf. Inf. V. 139-40.

99. See TC IV. 31-38, and cf. RVF 287.

100. See, for example, Mario Manlio Rossi, 'Laura morta e la concezione petrarchesca dell'aldilà', Studi petrarcheschi, 7 (1961), 301-21.

101. Pinelli, 'Feste e Trionfi', pp. 284-91.

102. For the Christian and Franciscan echoes of this epithet, see Marjorie O'Rourke Boyle, Petrarch's Genius: Pentimento and Prophecy (Berkeley: University of California Press, 1991), pp. 122-28.

\section{ORCID}

Laurence Hooper (D) http://orcid.org/0000-0002-4912-1108 